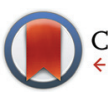

CrossMark \&lick for updates

Cite this: Dalton Trans., 2016, 45 1717

Received 23rd November 2015, Accepted 14th December 2015 DOI: $10.1039 / \mathrm{c} 5 \mathrm{dt} 04596 \mathrm{~g}$

www.rsc.org/dalton

\section{Access to novel fluorovinylidene ligands via exploitation of outer-sphere electrophilic fluorination: new insights into $\mathrm{C}-\mathrm{F}$ bond formation and activation $\uparrow$}

\author{
Lucy M. Milner, Lewis M. Hall, Natalie E. Pridmore, Matthew K. Skeats, \\ Adrian C. Whitwood, Jason M. Lynam* and John M. Slattery*
}

\begin{abstract}
Metal vinylidene complexes are widely encountered, or postulated, as intermediates in a range of important metal-mediated transformations of alkynes. However, fluorovinylidene complexes have rarely been described and their reactivity is largely unexplored. By making use of the novel outer-sphere electrophilic fluorination (OSEF) strategy we have developed a rapid, robust and convenient method for the preparation of fluorovinylidene and trifluoromethylvinylidene ruthenium complexes from non-fluorinated alkynes. Spectroscopic investigations (NMR and UV/Vis), coupled with TD-DFT studies, show that fluorine incorporation results in significant changes to the electronic structure of the vinylidene ligand. The reactivity of fluorovinylidene complexes shows many similarities to non-fluorinated analogues, but also some interesting differences, including a propensity to undergo unexpected $\mathrm{C}-\mathrm{F}$ bond cleavage reactions. Heating fluorovinylidene complex $\left[\mathrm{Ru}\left(\eta^{5}-\mathrm{C}_{5} \mathrm{H}_{5}\right)\left(\mathrm{PPh}_{3}\right)_{2}(\mathrm{C}=\mathrm{C}\{\mathrm{F}\} \mathrm{R})\right]\left[\mathrm{BF}_{4}\right]$ led to $\mathrm{C}-\mathrm{H}$ activation of a $\mathrm{PPh}_{3}$ ligand to form an orthometallated fluorovinylphosphonium ligand. Reaction with pyridine led to nucleophilic attack at the metal-bound carbon atom of the vinylidene to form a vinyl pyridinium species, which undergoes both $\mathrm{C}-\mathrm{H}$ and $\mathrm{C}-\mathrm{F}$ activation to give a novel pyridylidene complex. Addition of water, in the presence of chloride, leads to anti-Markovnikov hydration of a fluorovinylidene complex to form an $\alpha$-fluoroaldehyde, which slowly rearranges to its acyl fluoride isomer. Therefore, fluorovinylidenes ligands may be viewed as synthetic equivalents of 1-fluoroalkynes providing access to reactivity not possible by other routes.
\end{abstract}

\section{Introduction}

The unique properties of the carbon-fluorine bond can enhance many fundamental properties of biologically relevant molecules including bioavailability, metabolic stability and lipophilicity, with approximately $30 \%$ of agrochemicals and $20 \%$ of all pharmaceuticals now containing fluorine. ${ }^{1-9}$ The use of ${ }^{18}$ F-labelled imaging agents in positron emission tomography (PET) is also a highly active area of medical research. ${ }^{10,11}$ As such, new facile and selective synthetic methods for the introduction of fluorine into organic frameworks are highly desirable. Of particular interest are examples which offer high selectivity, controlled regiochemistry that is

Department of Chemistry, University of York, Heslington, York, YO10 5DD, UK. E-mail: jason.lynam@york.ac.uk, john.slattery@york.ac.uk; Fax: +44 (0)1904322516; Tel: +44 (0)1904322534, +44 (0)1904322610

$\dagger$ Electronic supplementary information (ESI) available: CIF data, experimental details, DFT methods and coordinates. CCDC 1040309-1040312 and 1419777-1419780. For ESI and crystallographic data in CIF or other electronic format see DOI: $10.1039 / \mathrm{c} 5 \mathrm{dt} 04596 \mathrm{~g}$ complementary to other methodologies and/or the ability to synthesise C-F bonds in less common environments.

The development of novel catalytic procedures for $\mathrm{C}-\mathrm{F}$ bond formation is highly desirable and can offer significant advantages over traditional stoichiometric processes. Recent years have seen many advances using enzymatic-, ${ }^{12}$ organo- or photo-catalytic ${ }^{13}$ methods for the synthesis of fluoro-organic compounds. Alongside these, transition-metal-promoted reactions have played an increasingly prominent role ${ }^{14}$ particularly in the formation of aryl fluorides. ${ }^{15}$ Complementary studies on C-F bond cleavage $e^{4,16-20}$ and hydrodefluorination by metal complexes provide insight into the functionalization of readily available fluorine-rich substrates. ${ }^{13,21-23}$

Metal-mediated C-F bond forming methodologies using both nucleophilic and electrophilic sources of fluorine have been developed. ${ }^{5,6,15,24}$ Our interest has focused on reactions involving electrophilic fluorinating reagents, a number of which are commercially available. ${ }^{25,26}$ They have been utilized in metal-catalyzed $\mathrm{C}-\mathrm{F}$ bond formation reactions, which are believed to proceed either by oxidative fluorination of palladium $^{27-29}$ or silver $^{30}$ to form a high-oxidation-state metal- 


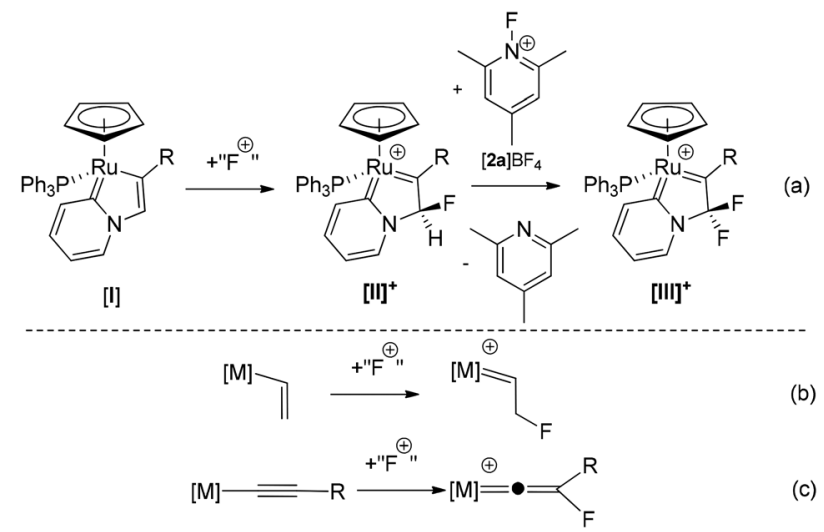

Scheme 1 Outer sphere electrophilic fluorination of an organo-ruthenium complex. " $\mathrm{F}^{+"}=$ [FTMP]BF ${ }_{4}$, Selectfluor or $\mathrm{N}$-fluorobenzenesulfonimide (NFSI).

fluoride complex ${ }^{31}$ followed by C-F reductive elimination, or through single-electron processes with either copper $^{32}$ or palladium catalysts. ${ }^{2,33-35}$ In addition, a wealth of Lewis-acidicmetal-mediated electrophilic fluorination reactions have been developed, which do not involve metal-based redox chemistry. ${ }^{36-39}$

We have recently described a new mechanism for the formation of $\mathrm{C}-\mathrm{F}$ bonds within the coordination sphere of a redox-active metal complex using electrophilic fluorinating reagents (Scheme 1a). ${ }^{40,41}$ Reaction of pyridylidene complex [I] with a latent source of " $\mathrm{F}^{+}$" results in selective $\mathrm{C}-\mathrm{F}$ bond formation to give $[\mathbf{I I}]^{+}$. Reaction of $[\mathbf{I I}]^{+}$with a further equivalent of 1-fluoro-2,4,6-trimethylpyridinium (FTMP) salt (in the presence of a catalytic amount of a base), or [I] with two equivalents of FTMP, gives the difluorinated analogue $[\mathbf{I I I}]^{+}$. Experimental and computational studies indicate that this process involves direct fluorination of the ligand, without $\mathrm{Ru}-\mathrm{F}$ bond formation, and is hence referred to as an outersphere electrophilic fluorination (OSEF) reaction.

We believe that the OSEF reaction in Scheme 1a is a general process and recent reports that an outer-sphere fluorination step may be involved in palladium-catalysed $\mathrm{C}-\mathrm{F}$ bond formation ${ }^{42}$ and the fluorination of alkyne ligands in the coordination sphere of platinum ${ }^{43}$ support this idea. It is therefore important to gain a deeper understanding of the scope of OSEF reactions and the reactivities of the novel fluorinated ligand systems that are formed.

The conversion of $[\mathbf{I}]$ to $[\mathbf{I I}]^{+}$may be viewed as the transformation of an alkenyl ligand to a fluorinated carbene (Scheme 1b) and by analogy we postulated that the corresponding reaction of an alkynyl ligand via OSEF might provide facile and selective formation of very unusual fluorovinylidene ligands (Scheme 1c). Fluorovinylidene complexes have rarely been described - limited examples of dimeric iridium ${ }^{44-47}$ and iron $^{48}$ complexes have been reported via activation of fluorinated organic precursors such as $\mathrm{H}_{2} \mathrm{C}=\mathrm{CHF}$ (iridium) and $\mathrm{CF}_{2}(\mathrm{COCl})_{2}$ (iron). Since the availability of these precursors with a range of substitution patterns is restricted, this approach does not represent a general method for the synthesis and exploitation of fluorovinylidenes complexes, and hence their reactivity is largely unexplored. However, the potential importance of these ligands as intermediates in catalytic processes is highlighted by the large number of catalytic reactions that proceed via non-fluorinated vinylidene intermediates. ${ }^{49-52}$

We now demonstrate the successful preparation of fluorovinylidene complexes by OSEF from readily available, nonfluorinated alkynes. Studies of their reactivity clearly demonstrate that these complexes may indeed provide important routes to fluorinated compounds. The fluorovinylidenes ligands may act as fluoroalkyne equivalents therefore offering access to reactivity patterns of compounds which are otherwise difficult to prepare and handle.

\section{Results and discussion}

\section{Synthesis and characterization of fluorine- and trifluoromethyl-containing vinylidene complexes}

By analogy with related electrophilic additions $\left(\mathrm{H}^{+},{ }^{53} \mathrm{Cl}_{2}, \mathrm{Br}_{2}\right.$, $\mathrm{I}_{2},{ }^{54} \mathrm{Au}\left(\mathrm{PPh}_{3}\right)^{+}$(ref. 55)), the electrophilic fluorination of the alkynyl ligand in $\left[\mathrm{Ru}\left(\eta^{5}-\mathrm{C}_{5} \mathrm{H}_{5}\right)(-\mathrm{C} \equiv \mathrm{CR})\left(\mathrm{PPh}_{3}\right)_{2}\right]$ to give fluorinated vinylidenes was targeted. Complexes based on the $\left[\mathrm{Ru}\left(\eta^{5}-\mathrm{C}_{5} \mathrm{H}_{5}\right)(-\mathrm{C} \equiv \mathrm{CPh})\left(\mathrm{PPh}_{3}\right)_{2}\right]$ were selected as metal-based precursors as they are readily available from the reaction between $\left[\mathrm{Ru}\left(\eta^{5}-\mathrm{C}_{5} \mathrm{H}_{5}\right) \mathrm{Cl}\left(\mathrm{PPh}_{3}\right)_{2}\right]$ and a wide range of terminal alkynes. ${ }^{56}$ Treatment of a $\mathrm{CH}_{2} \mathrm{Cl}_{2}$ solution of $\left[\mathrm{Ru}\left(\eta^{5}-\mathrm{C}_{5} \mathrm{H}_{5}\right)\right.$ $\left.(-\mathrm{C} \equiv \mathrm{CPh})\left(\mathrm{PPh}_{3}\right)_{2}\right],[\mathbf{1 a}]$, with [FTMP] $\mathrm{BF}_{4},[2 \mathrm{a}] \mathrm{BF}_{4}$, resulted in an instantaneous colour change from a yellow to a dark green solution from which the fluorinated vinylidene complex $\left[\mathrm{Ru}\left(\eta^{5}-\mathrm{C}_{5} \mathrm{H}_{5}\right)(=\mathrm{C}=\mathrm{C}\{\mathrm{F}\} \mathrm{Ph})\left(\mathrm{PPh}_{3}\right)_{2}\right] \mathrm{BF}_{4},[3 \mathbf{3 a}] \mathrm{BF}_{4}$, could be isolated in excellent yield (Scheme 2a). No intermediates were observed by NMR spectroscopy between $195 \mathrm{~K}$ and $295 \mathrm{~K}$, supporting the hypothesis that $[3 \mathrm{a}] \mathrm{BF}_{4}$ is being formed by direct fluorination of the alkynyl ligand. Complex $[3 \mathrm{a}] \mathrm{BF}_{4}$ could also be prepared in a one-pot procedure by treatment of the vinylidene complex $\left[\mathrm{Ru}\left(\eta^{5}-\mathrm{C}_{5} \mathrm{H}_{5}\right)(=\mathrm{C}=\mathrm{C}\{\mathrm{H}\} \mathrm{Ph})\left(\mathrm{PPh}_{3}\right)_{2}\right]^{+}$, $[\mathbf{4 a}]^{+}$, with base to generate $[\mathbf{1 a}]$ in situ followed by reaction with $[2 \mathrm{a}] \mathrm{BF}_{4}$. This reaction also proceeds in the absence of added base, but the reaction is slightly slower, requiring $c a .30 \mathrm{~min}$ to reach completion.

Analogous reactions of ruthenium alkynyl complexes containing both electron-releasing and electron-withdrawing

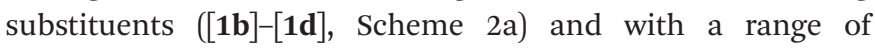
electrophilic fluorinating reagents (NFSI, $[2 \mathbf{b}] \mathrm{BF}_{4}$ and selectfluor, $\left.[2 \mathbf{c c}]\left(\mathrm{BF}_{4}\right)_{2}\right)$ proceeded with no notable difference in reaction outcome, demonstrating the generality of the approach. However, reaction of [1a] or [1 $\mathbf{b}]$ with 1-fluoropyridinium tetrafluoroborate, $[2 \mathrm{~d}] \mathrm{BF}_{4}$, resulted in the formation of the disubstituted vinylidene complexes $[\mathbf{5 a}] \mathrm{BF}_{4}$ and $[\mathbf{5 b}] \mathrm{BF}_{4}$ respectively (Scheme 2b), the structure of the latter was confirmed by X-ray crystallography (ESI $\dagger$ ). Complex $[\mathbf{5 a}] \mathrm{BF}_{4}$ appears to have been 


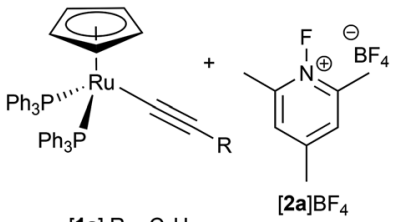

$[1 \mathrm{a}] \mathrm{R}=\mathrm{C}_{6} \mathrm{H}_{5}$
$[1 \mathbf{b}] \mathrm{R}=\mathrm{C}_{6} \mathrm{H}_{4}-4-\mathrm{CF}_{3}$ $[1 \mathrm{c}] \mathrm{R}=\mathrm{C}_{6} \mathrm{H}_{4}-4-\mathrm{OMe}$ [1d $\mathrm{R}={ }^{\mathrm{B}} \mathrm{Bu}$<smiles>[R]C#C[C@](P)(c1ccccc1)[Pb](F)(c1ccccc1)c1ccc[n+](F)c1</smiles>
$[1 \mathrm{a}] \mathrm{R}=\mathrm{C}_{6} \mathrm{H}_{5}$
$[1 \mathbf{b}] \mathrm{R}=\mathrm{C}_{6} \mathrm{H}_{4}-4-\mathrm{CF}_{3}$

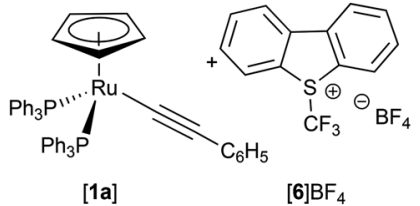

[1a]

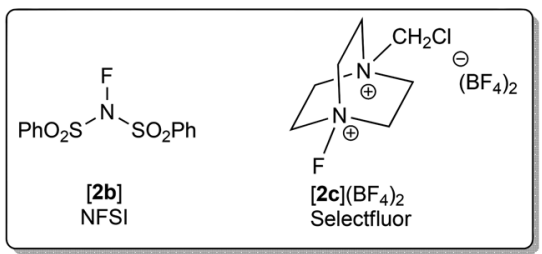

Scheme 2 (i) $\mathrm{CH}_{2} \mathrm{Cl}_{2}$ solution, -2,4,6-trimethylpyridine. *NFSI was used as the fluorinating agent. (ii) $\mathrm{CH}_{2} \mathrm{Cl}_{2}$ solution, -" $\mathrm{HF}$ " (iii) $\mathrm{CH}_{2} \mathrm{Cl}_{2}$ solution, 4 h, r.t., -dibenzothiophene.

formed by formal nucleophilic aromatic substitution of [2d] $\mathrm{BF}_{4}$ by the alkynyl ligand in [1a] with concomitant loss of HF.

In a similar manner to electrophilic fluorination, the electrophilic incorporation of $-\mathrm{CF}_{3}$ groups into the framework of organic compounds is also desirable. ${ }^{10,39,57,58}$ There are only limited examples of $\mathrm{CF}_{3}$-substituted vinylidene complexes, all of which are dimeric species formed from the activation of $\mathrm{H}_{2} \mathrm{C}=\mathrm{CHCF}_{3}{ }^{46}$ The reaction between [1a] and Umemoto's reagent, $[6] \mathrm{BF}_{4}$, (a latent source of " $\mathrm{CF}_{3}{ }^{+}$") resulted in the selective formation of $\left[\mathrm{Ru}\left(\eta^{5}-\mathrm{C}_{5} \mathrm{H}_{5}\right)\left(=\mathrm{C}=\mathrm{C}\left\{\mathrm{CF}_{3}\right\} \mathrm{Ph}\right)\left(\mathrm{PPh}_{3}\right)_{2}\right] \mathrm{BF}_{4}$, $[7 \mathbf{a}] \mathrm{BF}_{4}$ (Scheme 2c). The structure of $[7 \mathbf{a}] \mathrm{BF}_{4}$ was confirmed by a single crystal X-ray diffraction study (ESI $\dagger$ ). To the best of our knowledge complexes [3] $\mathrm{BF}_{4}$ are the first examples of fluorovinylidene ligands in mononuclear metal species, and access to these complexes has allowed an evaluation of the effects of fluorine incorporation into vinylidene ligands. For example, the ${ }^{19} \mathrm{~F}$ NMR spectrum of $[3 \mathrm{a}]^{+}$displayed a singlet resonance at $\delta-208.7$ for the fluorine atom of the vinylidene ligand and the ${ }^{13} \mathrm{C}\left\{{ }^{1} \mathrm{H}\right\}$ NMR spectrum exhibits a doublet of triplets at $\delta 389.0$ $\left({ }^{2} J_{\mathrm{CF}}=39.3 \mathrm{~Hz},{ }^{2} J_{\mathrm{CP}}=16.2 \mathrm{~Hz}\right)$ for the metal-bound carbon atom and a doublet at $\delta 196.7\left({ }^{1} J_{\mathrm{CF}}=222.1 \mathrm{~Hz}\right)$ for the fluorine-bearing carbon atom. These resonances are shifted
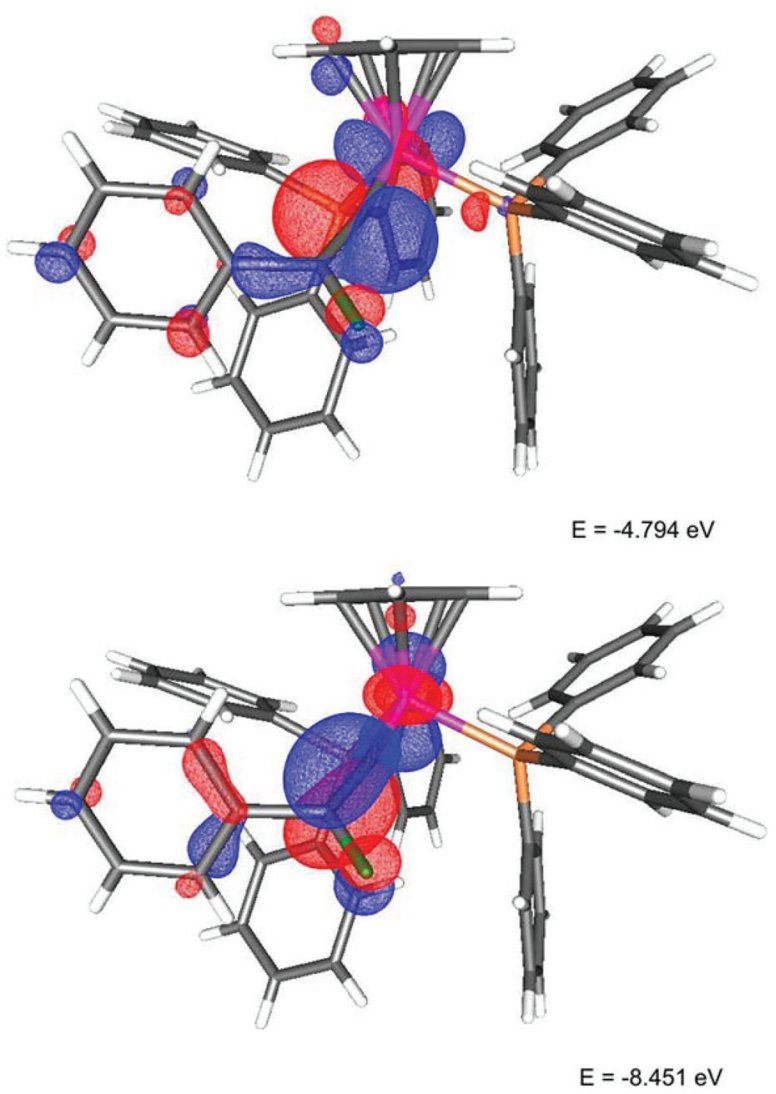

Fig. 1 LUMO (top) and HOMO (bottom) of [3a] ${ }^{+}$.

ca. $30 \mathrm{ppm}$ and $70 \mathrm{ppm}$ downfield, respectively, when compared to the hydrogen-substituted analogue $\left[\mathbf{4 a}^{2} \mathrm{PF}_{6}\right.$. Indeed the metal-bound carbon is observed at one of the lowest reported chemical shifts for a vinylidene $\alpha$-carbon..$^{59,60}$ In $\mathrm{CD}_{2} \mathrm{Cl}_{2}$ solution the ${ }^{1} \mathrm{H},{ }^{31} \mathrm{P}$ and ${ }^{19} \mathrm{~F}$ NMR spectra of $[3 \mathrm{a}] \mathrm{BF}_{4}$ showed no change on cooling to $195 \mathrm{~K}$, indicating that the vinylidene was undergoing rapid rotation on the NMR timescale.

The deep green colour of the fluorovinylidene complexes is due to an absorption band at $c a .690 \mathrm{~nm}$, which showed no significant solvatochromism (ESI $\dagger$ ). With the aid of TD-DFT studies this transition was shown to be dominated by HOMO $\rightarrow$ LUMO character. In the HOMO (Fig. 1) a fluorine lone pair has an anti-bonding interaction with the $\pi$-system of the vinylidene ligand (which is itself anti-bonding with respect to a metal-centred orbital). The LUMO has a contribution from a p-orbital on the fluorine and an orbital based on the metalbound carbon.

Additional spectroscopic data of the other halogen-substituted vinylidene complexes $\left[\mathrm{Ru}\left(\eta^{5}-\mathrm{C}_{5} \mathrm{H}_{5}\right)\left(=\mathrm{C}=\mathrm{C}\left\{\mathrm{E}_{\}} \mathrm{C}_{6} \mathrm{H} 4-4-\mathrm{R}\right)\right.\right.$ $\left.\left(\mathrm{PPh}_{3}\right)_{2}\right] \mathrm{X}^{54}(\mathrm{E}=\mathrm{Cl}, \ddagger \mathrm{Br}$ and $\mathrm{I})$ and the $\mathrm{CF}_{3}$-containing complex, $[7 \mathrm{a}] \mathrm{BF}_{4}$, support an interplay between $\sigma$ - and $\pi$-effects on the

$\$\left[8 \mathrm{a}^{\mathrm{Cl}}\right] \mathrm{BF}_{4}$ was prepared by a new method from $[\mathbf{1 a}]$ and $N$-chlorosuccinamide, $\left[\mathbf{8 a}^{\mathrm{Br}}\right] \mathrm{BF}_{4}$ was synthesised from one equivalent of $\mathrm{Br}_{2}$ and $\mathrm{NaBF}_{4}$, see ESI. 
Table 1 Summary of ${ }^{13} \mathrm{C}$ NMR data and lowest energy bands in the absorption spectra of vinylidene complexes. Experimental data were recorded at a concentration of ca. $1 \mathrm{mmol} \mathrm{dm}^{-3}$ in $\mathrm{CH}_{2} \mathrm{Cl}_{2}$ solution

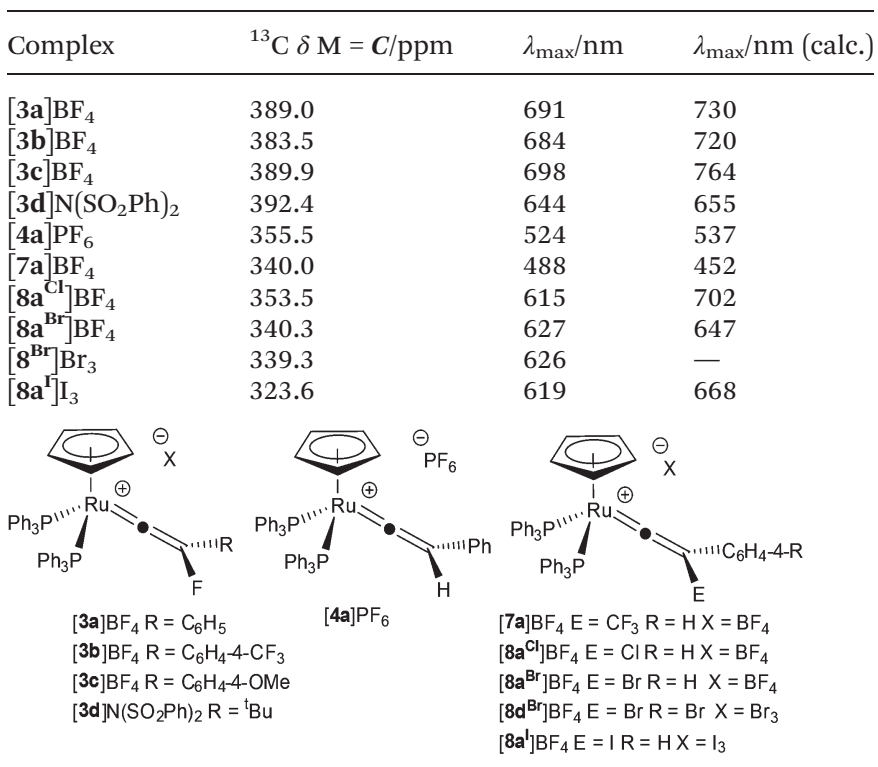

energy of the HOMO-LUMO transition (Table 1). Good $\pi$-donors $($ e.g. $\mathrm{F}, \mathrm{Cl}$ ) raise the energy of the HOMO, thereby lowering the energy of the HOMO-LUMO transition. In contrast, the strongly (-I) electron-withdrawing groups, such as $\mathrm{CF}_{3}$ in $[7 \mathrm{a}] \mathrm{BF}_{4}$ display a higher energy transition, presumably due to an opposite effect. This effect is supported by the bathochromic shift observed in methoxy-substituted $[3 \mathbf{c}] \mathrm{BF}_{4}$ and the hypsochromic shift in $[3 \mathbf{b}] \mathrm{BF}_{4}$. The interplay between $\sigma$ - and $\pi$-effects appears to also be manifested in the chemical shift of the metal bound carbon atom, as the $\mathrm{CF}_{3}$-subsituted vinylidene ligand has a chemical shift similar to $[\mathbf{4 a}] \mathrm{PF}_{6}$, but the halogen-substituted variants have a chemical shift range of $66 \mathrm{ppm}$.

Complex $[3 \mathrm{a}] \mathrm{PF}_{6}$ crystallises as two different polymorphs, which have significantly different photophysical properties in the solid state (Fig. 2). One is orange $\left(\lambda_{\max }=742 \mathrm{~nm}\right)$ and one green $\left(\lambda_{\max }=692 \mathrm{~nm}\right)$ and they differ primarily in the orientation of the fluorine atom and phenyl group of the vinylidene ligand and the geometry around the $\beta$-carbon (ESI $\dagger$ ). Dissolution of both crystals in $\mathrm{CH}_{2} \mathrm{Cl}_{2}$ gave essentially identical UVvis and NMR spectra showing that the two crystalline forms convert to the same species in solution. We propose that the observed species is a time-averaged signal for the different rotameric forms. Different agostic isomers of the same organometallic complex have been shown to produce crystals with markedly different electronic spectra, ${ }^{61}$ however, in the case of $[3 a] \mathrm{PF}_{6}$ subtle changes to the structure in the solid state has a pronounced effect on the photophysical properties of the system by altering the energy of the HOMO-LUMO transition.

\section{Reactions of fluorine-containing vinylidene complexes}

Attempted displacement of $\mathbf{F C} \equiv \mathbf{C P h}$. The facile syntheses of complexes $[3] \mathrm{BF}_{4}$ has allowed an exploration of the reactivity
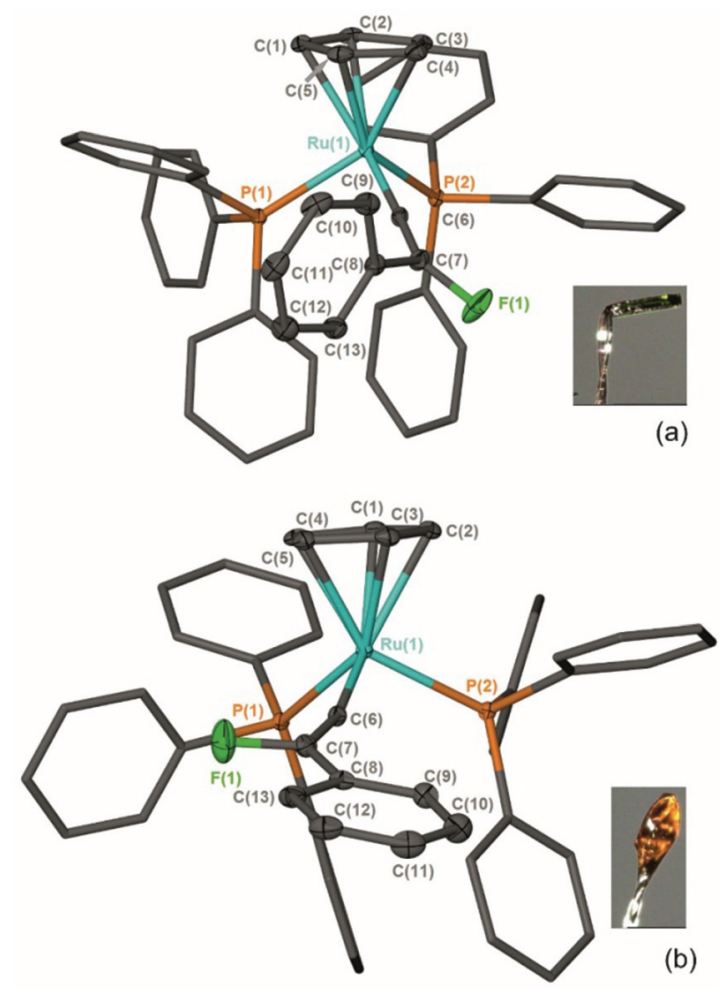

Fig. 2 Solid-state structures of the $[3 a]^{+}$cation found in (a) green crystals and (b) orange crystals. Hydrogen atoms removed for clarity and thermal ellipsoids (where shown) are at the $50 \%$ probability level.

of these species to evaluate the effects of fluorine incorporation into vinylidene ligands. In the case of half-sandwich ruthenium complexes with either mono- ${ }^{62,63}$ or di-substituted vinylidene ligands ${ }^{64}$ reaction with $\mathrm{NCMe}$ has been shown to reverse the alkyne-vinylidene tautomerisation and generate $\left[\mathrm{Ru}\left(\eta^{5}-\mathrm{L}\right)(\mathrm{NCMe})\left(\mathrm{PPh}_{3}\right)_{2}\right]^{+},\left(\mathrm{L}=\mathrm{C}_{5} \mathrm{H}_{5},\left[\mathbf{9}^{+}\right)\right.$liberating the corresponding alkynes $\mathrm{HC} \equiv \mathrm{CR}$ and $\mathrm{PhC} \equiv \mathrm{CR}$ respectively. These studies have permitted detailed kinetic insight into the nature of the alkyne-vinylidene interconversion. ${ }^{65}$ However, heating a sample of $[3 \mathbf{a}]^{+}$in $\mathrm{NCMe}_{3}$ did not result in an analogous reaction to form $[9]^{+}$and $\mathrm{FC} \equiv \mathrm{CPh}$. Instead, the major product from the reaction was $[\mathbf{1 0 a}] \mathrm{BF}_{4}$, in which a coordinated alkene ligand has been formed from a combination of vinylidene and phosphine ligands, the latter having undergone an orthometallation process (Scheme 3). The ${ }^{31} \mathrm{P}$ NMR spectrum of $[10 a] \mathrm{BF}_{4}$ exhibits two resonances at $\delta 46.6\left(\mathrm{dd},{ }^{3} J_{\mathrm{PF}}=48.6 \mathrm{~Hz}\right.$; $\left.{ }^{3} J_{\mathrm{PP}}=4.4 \mathrm{~Hz}\right)$ and $\delta 42.3\left(\mathrm{dd},{ }^{3} J_{\mathrm{PF}}=16.2 \mathrm{~Hz} ;{ }^{3} J_{\mathrm{PP}}=4.4 \mathrm{~Hz}\right)$

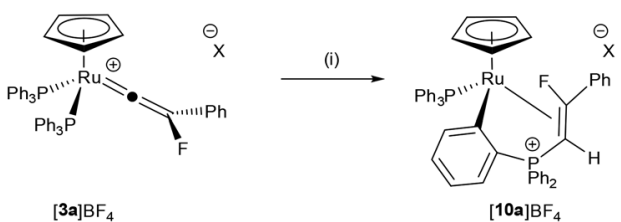

Scheme 3 (i) $\mathrm{NCMe}, 50{ }^{\circ} \mathrm{C}, 14 \mathrm{~d} . \mathrm{X}^{-}=\mathrm{BF}_{4}^{-}$or $\mathrm{N}\left(\mathrm{SO}_{2} \mathrm{Ph}\right)_{2}^{-}$. 
confirming the presence of two different phosphorus environments. Resonances at $\delta-143.4$ (app. dt, ${ }^{3} J_{\mathrm{PF}}=48.6 \mathrm{~Hz} ;{ }^{3} J_{\mathrm{HF}}=$ $16.9 \mathrm{~Hz} ;{ }^{3} J_{\mathrm{PF}}=16.2 \mathrm{~Hz}$ ) in the ${ }^{19} \mathrm{~F}$ NMR spectrum, $\delta 4.69$ (ddd, $\left.{ }^{3} J_{\mathrm{HF}}=16.9 \mathrm{~Hz} ;{ }^{2} J_{\mathrm{PH}}=5.0 \mathrm{~Hz} ;{ }^{3} J_{\mathrm{PH}}=1.7 \mathrm{~Hz}\right)$ in the ${ }^{1} \mathrm{H} \mathrm{NMR}$ spectrum and $113.7\left(\mathrm{dt},{ }^{1} J_{\mathrm{CF}}=243.0 \mathrm{~Hz} ;{ }^{2} J_{\mathrm{CP}}=5.6 \mathrm{~Hz}\right)$ and 25.9 (ddd, ${ }^{1} J_{\mathrm{CP}}=75.1 \mathrm{~Hz} ;{ }^{2} J_{\mathrm{CF}}=7.8 \mathrm{~Hz} ;{ }^{2} J_{\mathrm{CP}}=2.7 \mathrm{~Hz}$ ) in the ${ }^{13} \mathrm{C}\left\{{ }^{1} \mathrm{H}\right\}$ spectrum demonstrated that the fluorinated alkene ligand was present.

Other products form on heating at higher temperature $\left(80{ }^{\circ} \mathrm{C}\right)$, but after $c a$. two weeks at $50{ }^{\circ} \mathrm{C}$, the reaction was reasonably selective (70\% conversion based on ${ }^{31} \mathrm{P}$ NMR spectroscopy). A complex related to $[\mathbf{1 0 a}] \mathrm{BF}_{4}$ has been reported previously from the nucleophilic attack of $\mathrm{PPh}_{3}$ at a coordinated (protio)vinylidene. ${ }^{66}$ It is proposed that $[\mathbf{1 0 a}] \mathrm{BF}_{4}$ is formed by initial loss of $\mathrm{PPh}_{3}$, followed by attack of the free phosphine at the metal-bound carbon of the fluorovinylidene. $\mathrm{C}-\mathrm{H}$ activation and hydride migration subsequently leads to $[\mathbf{1 0 a}] \mathrm{BF}_{4}$. This is supported by the fact that the dppe-containing fluorovinylidene complex $\left[\mathrm{Ru}\left(\eta^{5}-\mathrm{C}_{5} \mathrm{H}_{5}\right)(=\mathrm{C}=\mathrm{C}\{\mathrm{F}\} \mathrm{Ph})\right.$ (dppe) $] \mathrm{N}\left(\mathrm{SO}_{2} \mathrm{Ph}\right)_{2},[3 \mathrm{e}] \mathrm{N}\left(\mathrm{SO}_{2} \mathrm{Ph}\right)_{2}$ (prepared from $\left[\mathrm{Ru}\left(\eta^{5}-\mathrm{C}_{5} \mathrm{H}_{5}\right)\right.$ $(-\mathrm{C} \equiv \mathrm{CPh})($ dppe $)]$ and $2 \mathbf{b})$ is unchanged on heating at $100{ }^{\circ} \mathrm{C}$ for 14 days in $\mathrm{NCMe}_{3}$. These data indicate that the conversion of the fluorovinylidene to its alkyne form does not proceed under any of these conditions.

Reaction of fluorovinylidene complex with pyridine: $\mathbf{C}-\mathbf{H}$ and $\mathbf{C}-\mathbf{F}$ bond activation. Many of the catalytic applications of ruthenium vinylidene complexes exploit the electrophilicity of the metal-bound carbon atom. ${ }^{49,50,52,67}$ For example, we have recently demonstrated that nucleophilic attack by pyridine at a coordinated vinylidene was a key step in ruthenium-mediated $\mathrm{C}-\mathrm{H}$ functionalization reactions, ${ }^{68}$ a process whereby the formation of pyridylidene-containing intermediates plays an important role. Dissolution of $\left[3 \mathrm{a}^{-} \mathrm{BF}_{4}\right.$ in pyridine results in the immediate formation of the vinyl complex $\left[\mathrm{Ru}\left(\eta^{5}-\mathrm{C}_{5} \mathrm{H}_{5}\right)\right.$ $\left.(-\mathrm{C}\{\mathrm{py}\}=\mathrm{C}\{\mathrm{F}\} \mathrm{Ph})\left(\mathrm{PPh}_{3}\right)_{2}\right] \mathrm{BF}_{4}, \quad($ py $=$ pyridine $), \quad\left[\mathbf{1 1}_{3}\right] \mathrm{BF}_{4}$ (Scheme 4), demonstrating that the incorporation of the fluorine substituent does not inhibit nucleophilic attack at the metal-bound carbon. In $\mathrm{CD}_{2} \mathrm{Cl}_{2}$ solution the ${ }^{19} \mathrm{~F}$ NMR spec-
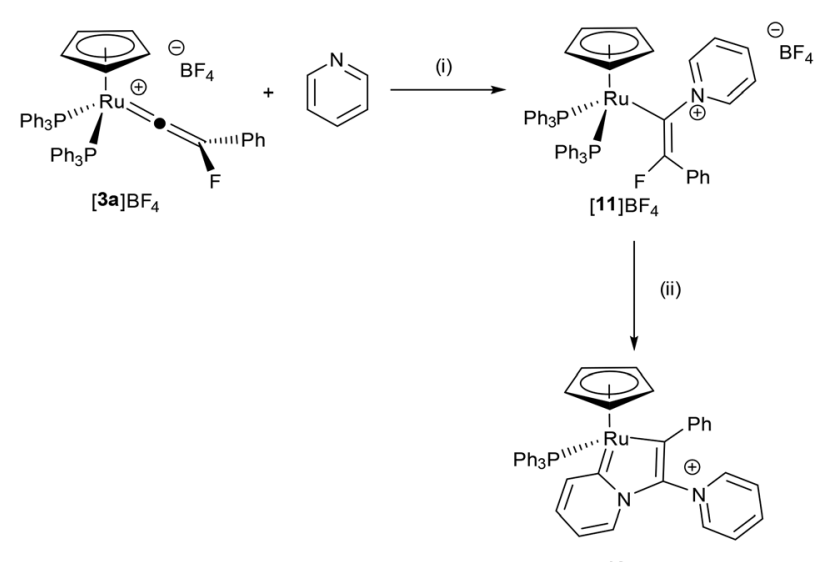

$[12] \mathrm{BF}_{4}$

Scheme 4 (i) Pyridine, $20^{\circ} \mathrm{C},<5 \mathrm{~min}$. (ii) Pyridine, $-\mathrm{HF}, 20^{\circ} \mathrm{C}, 10$ days.

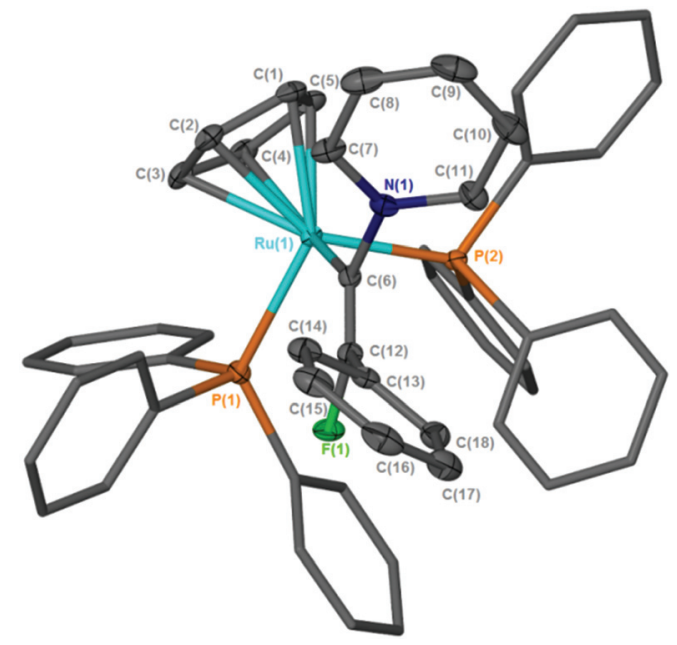

Fig. 3 Solid-state structure of the cation $[11]^{+}$, hydrogen atoms omitted for clarity, thermal ellipsoids (where shown) are at the 50\% probability level.

trum of $[11] \mathrm{BF}_{4}$ exhibited a doublet resonance at $\delta-71.1$ $\left({ }^{4} J_{\mathrm{PF}}=20.1 \mathrm{~Hz}\right)$ and the ${ }^{31} \mathrm{P}\left\{{ }^{1} \mathrm{H}\right\}$ a corresponding resonance at $\delta 44.0\left(\mathrm{~d},{ }^{4} J_{\mathrm{PF}}=20.3 \mathrm{~Hz}\right)$ : the ESI-MS demonstrated that a single pyridine had added to the ruthenium complex. The structure of $[\mathbf{1 1}] \mathrm{BF}_{4}$ was confirmed by X-ray crystallography (Fig. 3), which showed that the alkenyl ligand had adopted a $Z$-configuration. We have previously proposed that this type of alkenyl complex was a key intermediate in the direct $\mathrm{C}-\mathrm{H}$ functionalization of the pyridine, ${ }^{68}$ and the previous inability to observe such a species was principally owing to its low intrinsic concentration due to competitive deprotonation of the vinylidene ligand. Evidently, the presence of the fluorine atom allows for the observation and characterization of this species.

On standing in pyridine solution, $[\mathbf{1 1}] \mathrm{BF}_{4}$ underwent a further reaction to give $[\mathbf{1 2}] \mathrm{BF}_{4}$ and free $\mathrm{PPh}_{3}$. Monitoring this reaction by NMR spectroscopy indicated that this process proceeds through a number of phosphorus- and fluorine-containing intermediates. The molecular structure of $[\mathbf{1 2}] \mathrm{BF}_{4}$ (Fig. 4 as its pyridine solvate) showed that this species was a novel pyridylidene complex had been formed by activation of a $\mathrm{C}-\mathrm{H}$ bond of the pyridine group in $[\mathbf{1 1}] \mathrm{BF}_{4}$, incorporation of a second pyridine molecule and formal loss of HF, the fate of which could not be determined.

A potential mechanism for the conversion of $[3 \mathbf{a}] \mathrm{BF}_{4}$ to $[12] \mathrm{BF}_{4}$ was investigated by a DFT study. Given the changes in molecularity during the proposed mechanism there are significant differences in the relative zero-point-energy-corrected electronic energies $\left(E_{\mathrm{SCF}+\mathrm{ZPE}}\right)$ and Gibbs energies of different states. The following discussion refers solely to the Gibbs energies at $298 \mathrm{~K}$, although both are presented in Fig. 5. In the first step, nucleophilic attack of pyridine occurs at the metal-bound carbon atom of the vinylidene in $[3 \mathbf{a}]^{+}$(taken as the reference point for the calculations) to give $[\mathbf{1 1 - Z}]^{+}$through transition 


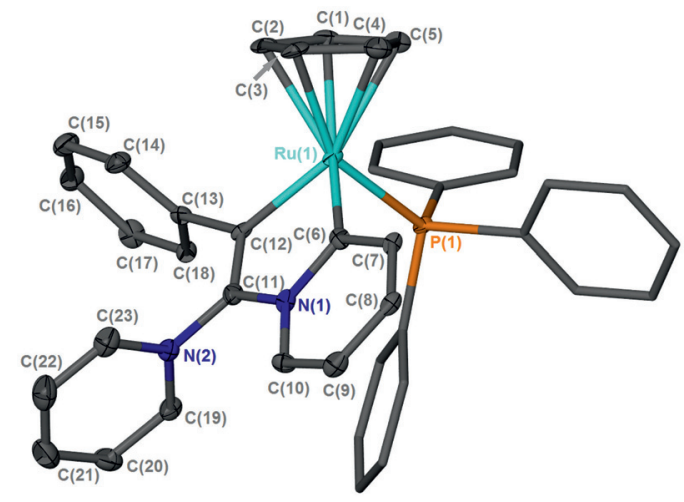

Fig. 4 Solid-state structure of one of the two crystallographically independent cations in the structure of $[12] \mathrm{BF}_{4}$.pyridine, hydrogen atoms omitted for clarity, thermal ellipsoids (where shown) are at the 50\% probability level.

state $\mathbf{T S}_{[3 \mathrm{a}]^{+}[\mathbf{1 1}-\mathrm{Z}]^{+}}$. The fact that $[\mathbf{1 1}]^{+}$is predicted to be lower in energy than $[\mathbf{3 a}]^{+}$and $\mathbf{T S}_{[3 \mathbf{a}]^{+}[11-\mathrm{z}]^{+}}$is reasonably accessible $\left(\Delta G^{\ddagger}{ }_{298}+100 \mathrm{~kJ} \mathrm{~mol}^{-1}\right)$ is consistent with the experimental observation of fast formation of [11] $\mathrm{BF}_{4}$.

The next stages in the reaction pathway are directly related to previous studies on pyridine C-H activation. ${ }^{68,69}$ Loss of $\mathrm{PPh}_{3}$ from $[\mathbf{1 1}]^{+}$leads to intermediate $[\mathbf{A}]^{+}$. Formation of agostic complex $[\mathbf{B}]^{+}$followed by $\mathrm{C}-\mathrm{H}$ activation via $\mathbf{T S}_{[\mathbf{B}]+[\mathrm{C}]^{+}}$ leads to hydride complex $[\mathbf{C}]^{+}$which may then undergo a subsequent migration to afford $[\mathbf{D}]^{+}$. A subsequent isomerisation to the lower energy isomer $[\mathbf{E}]^{+}$then occurs. Formal elimination of HF must then occur to give $[\mathbf{1 2}]^{+}$although attempts to model elimination of $\mathrm{HF}$ from $[\mathbf{E}]^{+}$via a pyridine-induced $E_{2^{-}}$ process were unsuccessful. However, deprotonation of $[\mathbf{E}]^{+}$(or hydride complex $[\mathbf{C}]^{+}$) may occur in pyridine solution to afford $[\mathbf{F}]$ and $\left[\mathrm{HNC}_{5} \mathrm{H}_{5}\right]^{+}$. Defluorination may now occur through $\mathrm{TS}_{[\mathrm{F}][\mathrm{G}]^{+}}$in which the $\left[\mathrm{HNC}_{5} \mathrm{H}_{5}\right]^{+}$aids the loss of the fluorine to give (after coordination of the triple bond in $[\mathbf{G}]^{+}$to the metal) alkyne complex $[\mathbf{H}]^{+}$. Nucleophilic attack by pyridine through $\mathbf{T S}_{[\mathrm{H}]^{+}[12]^{+}}$then gives the observed product $[\mathbf{1 2}]^{+}$, which is also the lowest point on the potential energy surface $\left(-45 \mathrm{~kJ} \mathrm{~mol}^{-1}\right)$.

The calculations indicate that the nucleophilic attack by pyridine of [3a $]^{+}$to give the $E$-isomer $\left([\mathbf{1 1}-\mathrm{E}]^{+}\right)$of the complex is both kinetically $\left(\mathbf{T S}_{[3 \mathrm{a}]^{+}[11-\mathrm{E}]^{+}}+155 \mathrm{~kJ} \mathrm{~mol}^{-1}\right)$ and thermodynamically unfavorable $\left(+65 \mathrm{~kJ} \mathrm{~mol}^{-1}\right)$ when compared to the formation of the $Z$-isomer. This appears to be due to an unfavourable interaction between the $\mathrm{PPh}_{3}$ ligands and the $\mathrm{Ph}$ group of the alkenyl ligand in the $E$-isomer. In contrast, however, defluorination from $[\mathbf{F}]$ is far more accessible from the $E$-isomer of the alkene complex ([F-E]) than from the $Z$-isomer $\left(\mathbf{T S}_{[\mathrm{F}-\mathrm{E}][\mathrm{G}]^{+}}+140 \mathrm{~kJ} \mathrm{~mol}^{-1} ; \mathbf{T S}_{[\mathrm{F}-\mathrm{Z}][\mathrm{G}]^{+}}+173 \mathrm{~kJ} \mathrm{~mol}^{-1}\right.$, see ESI $\dagger$ for full $E$ - and $Z$-pathways). There are a number of possible points on the PES where interconversion of the $E$ - and $Z$-isomers may occur. For example, previous calculations indicate that the vinylidene complexes, $[\mathbf{I}-\mathbf{Z}]^{+}$and $[\mathbf{I}-\mathbf{E}]^{+}$(Fig. 6a) would be readily accessible from complexes such as $[\mathbf{A}]^{+} .^{39}$ Rotation of vinylidene ligands, which will interchange the $E$ and $Z$-isomers, is a low energy process. ${ }^{70,71}$ We tentatively propose that at some point following state $[\mathbf{1 1 - Z}]^{+}$the system isomerises and follows the $E$-isomer pathway.

The formation of $[\mathbf{1 1}]^{+}$is rapid and a second, slower, reaction subsequently gives $[\mathbf{1 2}]^{+}$. In addition to supporting our previous observation that the $\left[\mathrm{Ru}\left(\eta^{5}-\mathrm{C}_{5} \mathrm{H}_{5}\right)\left(\mathrm{PPh}_{3}\right)\right]^{+}$fragment may selectively activate pyridine in the 2-position, ${ }^{68,72}$ the DFT study also provides an explanation as to why no alkenylated pyridine is observed in the fluorine-containing system. The key transition state in this process involves $\mathrm{C}-\mathrm{N}$ bond cleavage in [F-E] via TS $_{[\mathrm{F}-\mathrm{E}][\mathrm{J}-\mathrm{E}]}$ which at $+150 \mathrm{~kJ} \mathrm{~mol}^{-1}$ lies higher in energy than $\mathbf{T S}_{[\mathrm{F}-\mathrm{E}][\mathbf{G}]^{+}}$(Fig. 6b) implying that defluorination is preferred to $\mathrm{C}-\mathrm{N}$ bond cleavage.

It appears that $\mathrm{C}-\mathrm{F}$ bond cleavage in this system occurs by a pyridinium-assisted fluoride abstraction. This process is related

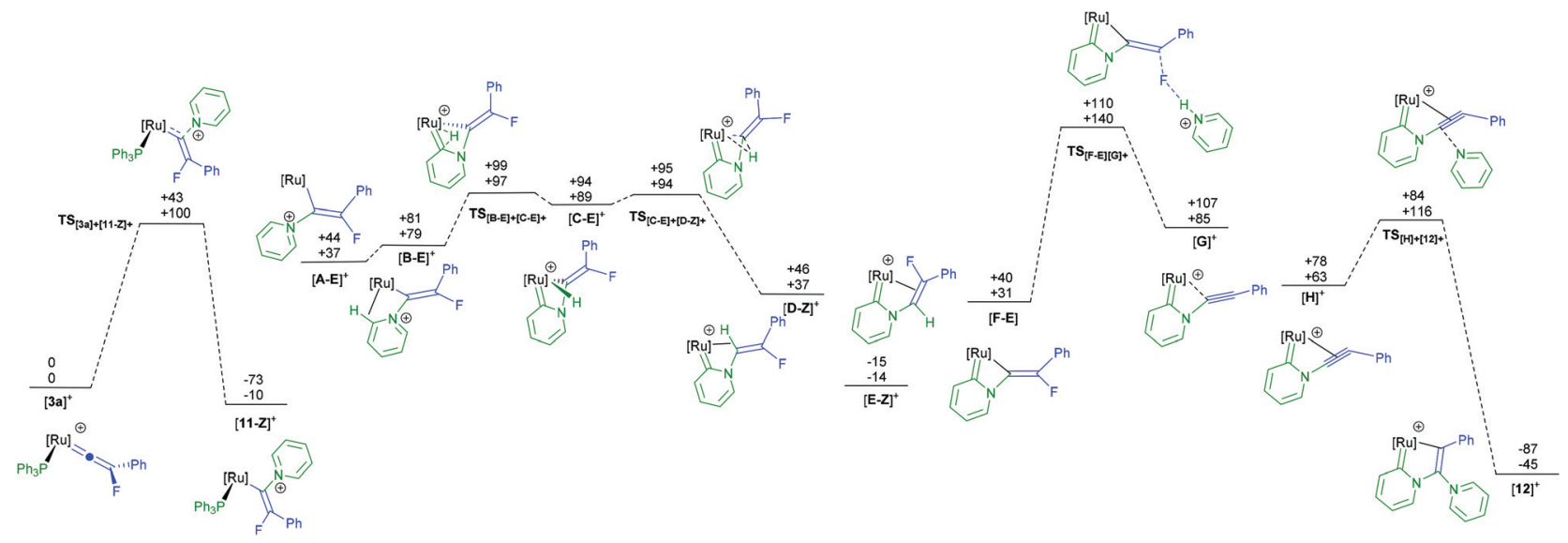

Fig. 5 Potential energy surface for the proposed mechanism of formation of $[12]^{+}$from $[3 \mathrm{a}]^{+}$. $E_{\mathrm{SCF}+\mathrm{ZPE}}$ (top) and Gibbs energies at $298.15 \mathrm{~K}$ (bottom), relative to $[3 \mathrm{a}]^{+}$and two molecules of pyridine, are shown in $\mathrm{kJ} \mathrm{mol}^{-1}$. Calculations are at the (RI-)PBE0-D3/def2-TZVPP//(RI-)BP86/SV(P) level with COSMO solvation in pyridine. $[\mathrm{Ru}]=\left[\mathrm{Ru}\left(\eta^{5}-\mathrm{C}_{5} \mathrm{H}_{5}\right)\left(\mathrm{PPh}_{3}\right)\right]$. 

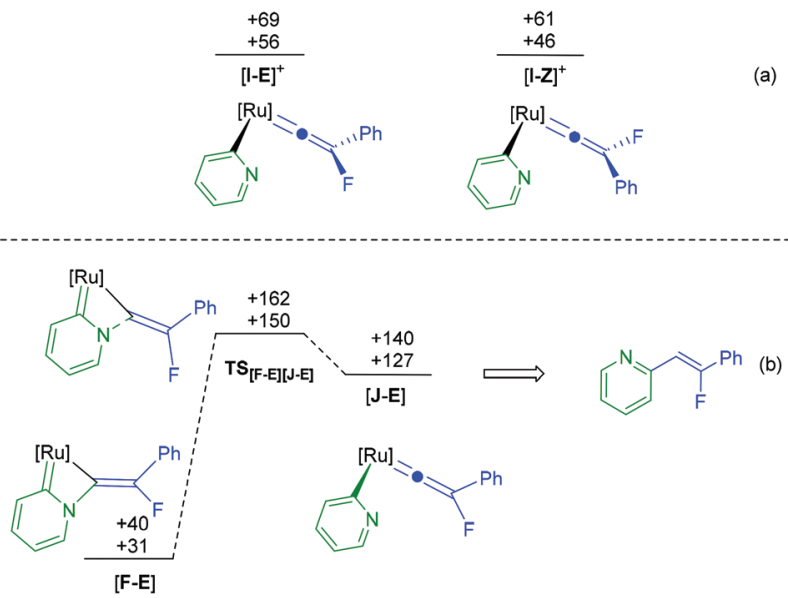

Fig. 6 Calculations at the (RI-)PBE0-D3/def2-TZVPP//(RI-)BP86/SV(P) level with COSMO solvation in pyridine. $[\mathrm{Ru}]=\left[\mathrm{Ru}\left(\eta^{5}-\mathrm{C}_{5} \mathrm{H}_{5}\right)\left(\mathrm{PPh}_{3}\right)\right]$. $E_{\mathrm{SCF}+\mathrm{ZPE}}$ (top) and Gibbs energies at $298.15 \mathrm{~K}$ (bottom), relative to [3a] ${ }^{+}$, pyridine and $\mathrm{PPh}_{3}$.

to Hughes' studies on half-sandwich iridium complexes in which $\alpha$-fluoride abstraction leads to a cationic carbene complex. ${ }^{73,74}$

In this case, a cationic alkyne complex is the product of the fluoride loss from the $\beta$-position of complex [F], which then undergoes nucleophilic attack by pyridine.

Hydrolysis of fluorovinylidene complexes: formation of an $\boldsymbol{\alpha}$-fluoroaldehyde and acyl-fluoride. The observation that fluorovinylidenes ligands are susceptible to nucleophilic attack, in a similar way to their non-fluorinated analogues, prompted us to explore this type of reaction with a view to generating fluorinated organic molecules. Vinylidene complexes are well known to undergo hydrolysis and hydration via nucleophilic attack of water at the $\alpha$-carbon of the vinylidene. ${ }^{75,76}$ The products of hydration depend on the ligands present at the metal. Careful design has allowed the development of Ru-catalysts for the anti-Markovnikov hydration of terminal alkynes via vinylidene intermediates. ${ }^{77-81,82}$ We were therefore interested in understanding the reactivity of $[3] \mathrm{BF}_{4}$ with water. However, $[3 \mathbf{a}] \mathrm{BF}_{4}$ proved to be relatively stable in the presence of water, in the absence of other additives. Addition of either stoichiometric or excess water to a $\mathrm{CH}_{2} \mathrm{Cl}_{2}$ solution of $[3 \mathbf{a}] \mathrm{BF}_{4}$ at room temperate did not result in an immediate reaction. Addition of one equivalent of a base, 1,4-diazabicyclo[2.2.2]octane (DABCO), and water (either stoichiometric water or ten equivalents) resulted in the formation of a number of new compounds. The major new species were identified, by ${ }^{31} \mathrm{P}\left\{{ }^{1} \mathrm{H}\right\}$ NMR spectroscopy, as $\left[\mathrm{Ru}\left(\eta^{5}-\mathrm{C}_{5} \mathrm{H}_{5}\right) \mathrm{Cl}\left(\mathrm{PPh}_{3}\right)_{2}\right],[13]$, and, remarkably, $\left[\mathrm{Ru}\left(\eta^{5}-\mathrm{C}_{5} \mathrm{H}_{5}\right)\right.$ $\left.(\mathrm{C} \equiv \mathrm{CPh})\left(\mathrm{PPh}_{3}\right)_{2}\right],[\mathbf{1 a}]$ the latter corresponding to the formal loss of " $\mathrm{F}$ " from the fluorovinylidene. ${ }^{83}$ Monitoring the reactions over an extended period ( $c a$. two weeks) at room temperature showed almost total conversion to [13]. Heating the reactions at $50{ }^{\circ} \mathrm{C}$ increased the rate of conversion but not the final product distribution. This should be contrasted with the reaction of $[\mathbf{4 a}]^{+}$with water which results in the formation of $\left[\mathrm{Ru}\left(\eta^{5}-\mathrm{C}_{5} \mathrm{H}_{5}\right)(\mathrm{CO})\left(\mathrm{PPh}_{3}\right)_{2}\right]^{+}$and toluene. ${ }^{76}$
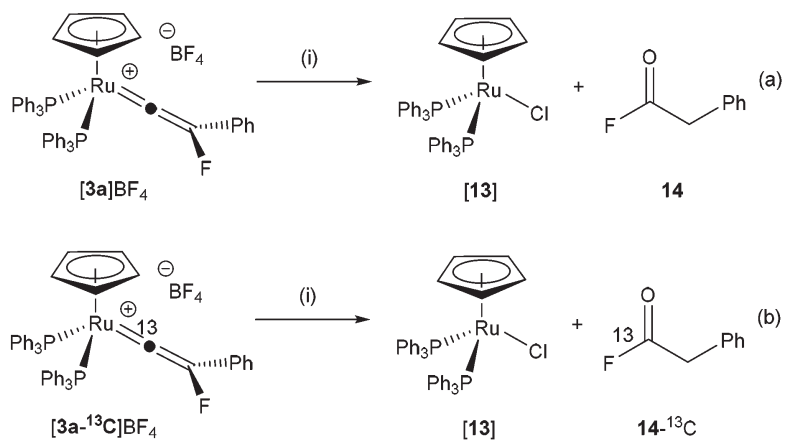

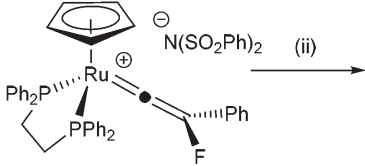

$[3 \mathrm{e}] \mathrm{N}\left(\mathrm{SO}_{2} \mathrm{Ph}\right)_{2}$

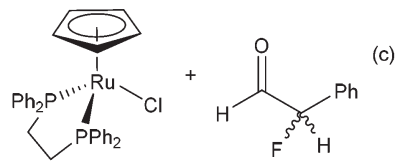

$[15$

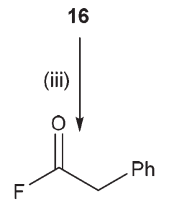

14
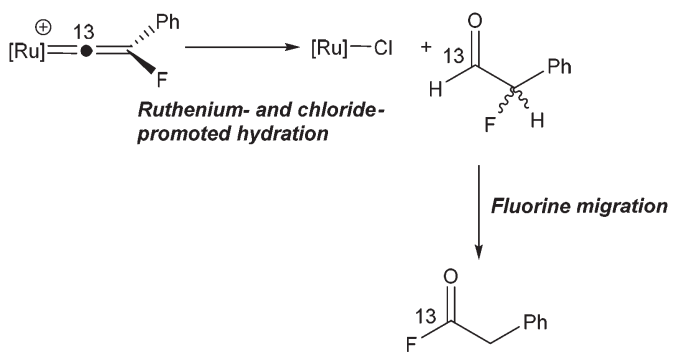

Scheme 5 (i) $\mathrm{CD}_{2} \mathrm{Cl}_{2}$, $+\mathrm{N}^{n} \mathrm{Bu}_{4} \mathrm{Cl},-\mathrm{N}^{n} \mathrm{Bu}_{4} \mathrm{BF}_{4}$, R. T., 14 d. (ii) $\mathrm{CD}_{2} \mathrm{Cl}_{2}$, $+\mathrm{N}^{n} \mathrm{Bu}_{4} \mathrm{Cl},-\mathrm{N}^{n} \mathrm{Bu}_{4}\left(\mathrm{SO}_{2} \mathrm{Ph}\right)_{2}$, R. T. (iii) 6 d, R. T.

In contrast, hydrolysis of $\left[3 \mathrm{a}^{-} \mathrm{BF}_{4}\right.$ in the presence of chloride as an additive (introduced as $\mathrm{N}^{n} \mathrm{Bu}_{4} \mathrm{Cl} \cdot \mathrm{H}_{2} \mathrm{O} \S$ ) results in the selective, if slow, formation of $\left[\mathrm{Ru}\left(\eta^{5}-\mathrm{C}_{5} \mathrm{H}_{5}\right) \mathrm{Cl}\left(\mathrm{PPh}_{3}\right)_{2}\right],[13]$ and the acyl-fluoride $\mathbf{1 4}$ (Scheme 5a), which has resulted from formal hydration of the vinylidene ligand and isomerisation of the resulting $\alpha$-fluoroaldehyde (vide infra). Compound $\mathbf{1 4}$ was identified on the basis of characteristic resonances in the ${ }^{19} \mathrm{~F}\left(\delta 43.7, \mathrm{t},{ }^{3} J_{\mathrm{HF}}=1.5 \mathrm{~Hz}\right),{ }^{1} \mathrm{H}\left(\delta 3.84, \mathrm{~d},{ }^{3} J_{\mathrm{HF}}=1.5 \mathrm{~Hz}\right)$, and ${ }^{13} \mathrm{C}\left\{{ }^{1} \mathrm{H}\right\}$ NMR spectra $\left(\delta 39.2, \mathrm{~d},{ }^{2} J_{\mathrm{CF}}=54 \mathrm{~Hz}, C_{\mathrm{H}} ; 162.1\right.$, d, $\left.{ }^{2} J_{\mathrm{CF}}=362.3 \mathrm{~Hz}, \boldsymbol{C O F}\right)$ matching those previously reported. ${ }^{84}$ Monitoring the reaction by NMR spectroscopy demonstrated that [13] and $\mathbf{1 4}$ were formed at approximately the same rate. Compound $\mathbf{1 4}$ was isolated by sublimation and proved to be highly moisture sensitive.

The formation of $\mathbf{1 4}$ is somewhat surprising as it appears that either fluoro- or phenyl-migration must have occurred. Given that the reaction of $[3 \mathrm{a}] \mathrm{BF}_{4}$ with $\mathrm{NCMe}$ did not give rise to the alkyne $\mathrm{FC} \equiv \mathrm{CPh}$ and $[\mathbf{9}] \mathrm{BF}_{4}$ (which would also require

§ The ratio of $\mathrm{N}^{n} \mathrm{Bu}_{4} \mathrm{Cl}$ to $\mathrm{H}_{2} \mathrm{O}$ was shown to be $c a .1: 1$ by elemental analysis. 
$\mathrm{F}$ or Ph migration) it might be presumed that these are highenergy pathways in this system, although phenyl-migration in di-substituted vinylidene complexes is well established. ${ }^{64,85-88}$ In order to gain further mechanistic insight into this process, the ${ }^{13} \mathrm{C}$-enriched vinylidene complex $\left[3 \mathrm{a}^{-13} \mathrm{C}\right] \mathrm{BF}_{4}$ was prepared and subjected to an identical reaction with $\mathrm{N}^{n} \mathrm{Bu}_{4} \mathrm{Cl} \cdot \mathrm{H}_{2} \mathrm{O}$ (Scheme 5b). Analysis of the resulting ${ }^{19} \mathrm{~F}$ NMR spectra demonstrated that the resonance for $\mathbf{1 4}$ now appeared as a doublet $\left({ }^{1} J_{\mathrm{CF}}=361.4 \mathrm{~Hz}\right)$ with no evidence of a species with the labelled atom in the alternative position. Repeating the reaction with $[3 \mathbf{3 a}]^{+}$as the benzenesulfonimide salt (prepared from [1a] and NFSI) also gave 14, indicating that the source of the fluorine was the vinylidene ligand not the $\left[\mathrm{BF}_{4}\right]^{-}$counteranion.

Hydrolysis of the dppe-containing complex $[3 \mathbf{e}] \mathrm{N}\left(\mathrm{SO}_{2} \mathrm{Ph}\right)_{2}$ in the presence of chloride (as $\mathrm{N}^{n} \mathrm{Bu}_{4} \mathrm{Cl} \cdot \mathrm{H}_{2} \mathrm{O}$ ) is much faster than the $\mathrm{PPh}_{3}$-containing analogue. At room temperature rapid formation of $\left[\mathrm{Ru}\left(\eta^{5}-\mathrm{C}_{5} \mathrm{H}_{5}\right) \mathrm{Cl}(\mathrm{dppe})\right]$, [15] and the $\alpha$-fluoroaldehyde 16 (identified by resonances in the ${ }^{1} \mathrm{H}$ and ${ }^{19} \mathrm{~F}$ NMR spectra at $\delta 9.72\left(\mathrm{dd},{ }^{3} J_{\mathrm{HF}}=7.6 \mathrm{~Hz},{ }^{5} J_{\mathrm{HH}}=0.7 \mathrm{~Hz}\right.$ and $\delta-191.7$ (dd, ${ }^{2} J_{\mathrm{HF}}=47.0 \mathrm{~Hz},{ }^{3} J_{\mathrm{HF}}=7.6 \mathrm{~Hz}$ ) respectively) was observed, Scheme $5 c{ }^{89}$ Over the course of 6 days the resonances for $\mathbf{1 6}$ decreased in intensity to be replaced by those for $\mathbf{1 4}$. It is proposed that anti-Markovnikov hydration of the vinylidene $e^{77-79,82}$ occurs to give 16 which then undergoes a slower isomerisation to 14. DFT calculations indicate that 16 is $97 \mathrm{~kJ} \mathrm{~mol}^{-1}$ higher in energy $\left(\Delta G_{298}\right)$ than $\mathbf{1 4}$ so this conversion is thermodynamically favoured and aldehydes such as $\mathbf{1 6}$ have been reported to be unstable. ${ }^{90}$ The overall process is summarised in Scheme $5 \mathrm{~d}$.

The reaction of metal alkynyl complexes (derived from terminal alkynes) with " $\mathrm{F}^{+}$" followed by hydrolysis and liberation of $\alpha$-fluoroaldehydes represents a stepwise functionalization of alkynes with the incorporation of both new functionality and the generation of a new stereocentre. This type of reactivity is highly desirable as the fluorinated vinylidene ligands are effectively acting as synthetic equivalents of 1-fluoroalkynes. Work is underway in our groups to exploit these stoichiometric observations for the development of catalytic protocols for combined alkyne functionalization and fluorination.

\section{Conclusions}

The reaction between alkynyl complexes [1] and electrophilic fluorinating and trifluoromethylating agents offers a highly selective and simple route for the direct formation of $\mathrm{C}-\mathrm{F}$ and $\mathrm{C}-\mathrm{CF}_{3}$ bonds and the construction of novel fluorinated vinylidene ligands. Although the addition of other electrophiles to alkynyl complexes has been reported, it is remarkable that the highly oxidising sources of " $\mathrm{F}^{+}$" result in selective $\mathrm{C}-\mathrm{F}$ bond formation rather than direct fluorination of the metal complexes. These data demonstrate that OSEF (or analogous trifluoromethylation) represents a complementary approach to current metal-mediated routes for electrophilic $\mathrm{C}-\mathrm{F}$ bond formation and may be applicable to a range of organometallic systems.

As the new fluorinated ligands were retained within the coordination sphere of ruthenium it was possible to evaluate the effects of incorporation of the fluorine and explore subsequent reactivity. Reactions of fluorovinylidene complexes with nucleophiles such as pyridine and water show many similarities to the reactivity of non-fluorinated vinylidenes. As these $^{25}$ are important intermediates in a range of metal-catalysed reactions, this suggests that access to fluorinated analogues offers new opportunities for the formation of novel fluorinated organic compounds without re-writing the rule book in terms of their reactivity. Indeed, our observation of anti-Markovnikov hydration of fluorovinylidenes, a key reaction of non-fluorinated analogues, to form both new functionality and a new stereocentre in the $\alpha$-fluoroaldehyde products supports this argument. In addition to applications in synthesis, the introduction of fluorine into ligands of organometallic complexes may significantly alter metal-ligand bonding and, for example, may be used to blue-shift the emission from luminescent iridium complexes. ${ }^{91-94}$ In summary, it has been demonstrated how OSEF allows for the facile formation of $\mathrm{C}-\mathrm{F}$ (and $\mathrm{C}-\mathrm{CF}_{3}$ bonds) in metal alkynyl complexes to be achieved and that $\mathrm{C}-\mathrm{F}$ bond cleavage, assisted by a pyridinium salt, may occur from the $\beta$-position of an organic ligand.

\section{Acknowledgements}

We thank the EPSRC (DTA studentship to LMM and computational equipment EP/H011455/1 and EP/K031589/1) and the University of York (PhD Studentship to LMH and summer studentship to MKS) for funding. The insightful comments of Professors Duncan Bruce and Robin Perutz on this work are gratefully acknowledged.

\section{Notes and references}

1 X. Yang, T. Wu, R. J. Phipps and F. D. Toste, Chem. Rev., 2015, 115, 826-870.

2 Z. Jin, G. B. Hammond and B. Xu, Aldrichimica Acta, 2012, 45, 67-83.

3 T. Besset, T. Poisson and X. Pannecoucke, Chem. - Eur. J., 2014, 20, 16830-16845.

4 T. Furuya, A. S. Kamlet and T. Ritter, Nature, 2011, 473, 470-477.

5 T. Liang, C. N. Neumann and T. Ritter, Angew. Chem., Int. Ed., 2013, 52, 8214-8264.

6 X. Yang, T. Wu, R. J. Phipps and F. D. Toste, Chem. Rev., 2015, 115, 826-870.

7 T. Furuya, J. E. M. N. Klein and T. Ritter, Synthesis, 2010, 1804-1821.

8 C. N. Neumann and T. Ritter, Angew. Chem., Int. Ed., 2015, 54, 3216-3221. 
9 M. G. Campbell and T. Ritter, Org. Process Res. Dev., 2014, 18, 474-480.

10 S. Purser, P. R. Moore, S. Swallow and V. Gouverneur, Chem. Soc. Rev., 2008, 37, 320-330.

11 E. Lee, A. S. Kamlet, D. C. Powers, C. N. Neumann, G. B. Boursalian, T. Furuya, D. C. Choi, J. M. Hooker and T. Ritter, Science, 2011, 334, 639-642.

12 D. O'Hagan and H. Deng, Chem. Rev., 2015, 115, 634649.

13 S. M. Senaweera, A. Singh and J. D. Weaver, J. Am. Chem. Soc., 2014, 136, 3002-3005.

14 T. Ahrens, J. Kohlmann, M. Ahrens and T. Braun, Chem. Rev., 2015, 115, 931-972.

15 M. G. Campbell and T. Ritter, Chem. Rev., 2015, 115, 612633.

16 M. Reinhold, J. E. McGrady and R. N. Perutz, J. Am. Chem. Soc., 2004, 126, 5268-5276.

17 E. Clot, O. Eisenstein, N. Jasim, S. A. Macgregor, J. E. McGrady and R. N. Perutz, Acc. Chem. Res., 2011, 44, 333-348.

18 B. Procacci, Y. Jiao, M. E. Evans, W. D. Jones, R. N. Perutz and A. C. Whitwood, J. Am. Chem. Soc., 2015, 137, 12581272 .

19 M. E. Evans, C. L. Burke, S. Yaibuathes, E. Clot, O. Eisenstein and W. D. Jones, J. Am. Chem. Soc., 2009, 131, 13464-13473.

20 E. Clot, C. Mégret, B. M. Kraft, O. Eisenstein and W. D. Jones, J. Am. Chem. Soc., 2004, 126, 5647-5653.

21 M. F. Kuehnel, D. Lentz and T. Braun, Angew. Chem., Int. Ed., 2013, 52, 3328-3348.

22 M. K. Whittlesey and E. Peris, ACS Catal., 2014, 4, 31523159.

23 G. Meier and T. Braun, Angew. Chem., Int. Ed., 2009, 48, 1546-1548.

24 A. J. Cresswell, S. G. Davies, P. M. Roberts and J. E. Thomson, Chem. Rev., 2015, 115, 566-611.

25 A. G. Gilicinski, G. P. Pez, R. G. Syvret and G. S. Lal, J. Fluorine Chem., 1992, 59, 157-162.

26 E. W. Oliver and D. H. Evans, J. Electroanal. Chem., 1999, 474, 1-8.

27 T. Furuya and T. Ritter, J. Am. Chem. Soc., 2008, 130, 1006010061.

28 T. Furuya, D. Benitez, E. Tkatchouk, A. E. Strom, P. Tang, W. A. Goddard and T. Ritter, J. Am. Chem. Soc., 2010, 132, 3793-3807.

29 N. D. Ball and M. S. Sanford, J. Am. Chem. Soc., 2009, 131, 3796-3797.

30 P. Tang, T. Furuya and T. Ritter, J. Am. Chem. Soc., 2010, 132, 12150-12154.

$31 \mathrm{C}-\mathrm{F}$ reductive elimination from a $\mathrm{Au}(\mathrm{III})$ fluoride, generated by oxdiation of a $\mathrm{Au}(\mathrm{I})$ complex by $\mathrm{XeF}_{2}$ has also been reported, N. P. Mankad and F. D. Toste, Chem. Sci., 2012, 3, 72-76.

32 C. R. Pitts, S. Bloom, R. Woltornist, D. J. Auvenshine, L. R. Ryzhkov, M. A. Siegler and T. Lectka, J. Am. Chem. Soc., 2014, 136, 9780-9791.
33 K. M. Engle, T.-S. Mei, X. Wang and J.-Q. Yu, Angew. Chem., Int. Ed., 2011, 50, 1478-1491.

34 A. R. Mazzotti, M. G. Campbell, P. Tang, J. M. Murphy and T. Ritter, J. Am. Chem. Soc., 2013, 135, 14012-14015.

35 J. R. Brandt, E. Lee, G. B. Boursalian and T. Ritter, Chem. Sci., 2014, 5, 169-179.

36 L. Hintermann and A. Togni, Angew. Chem., Int. Ed., 2000, 39, 4359-4362.

37 S. Piana, I. Devillers, A. Togni and U. Rothlisberger, Angew. Chem., Int. Ed., 2002, 41, 979-982.

38 M. Althaus, C. Becker, A. Togni and A. Mezzetti, Organometallics, 2007, 26, 5902-5911.

39 J. Charpentier, N. Früh and A. Togni, Chem. Rev., 2015, 115, 650-682.

40 L. M. Milner, N. E. Pridmore, A. C. Whitwood, J. M. Lynam and J. M. Slattery, J. Am. Chem. Soc., 2015, 137, 1075310759.

41 L. M. Hall, J. M. Lynam, L. M. Milner and J. M. Slattery, UK Pat, GB1421598.2, 2014.

42 C. Testa, J. Roger, S. Scheib, P. Fleurat-Lessard and J.-C. Hierso, Adv. Synth. Catal., 2015, 357, 2913-2923.

43 J. Berger, T. Braun, R. Herrmann and B. Braun, Dalton Trans., 2015, 44, 19553-19565.

44 M. E. Slaney, D. J. Anderson, M. J. Ferguson, R. McDonald and M. Cowie, J. Am. Chem. Soc., 2010, 132, 16544-16558.

45 M. E. Slaney, M. J. Ferguson, R. McDonald and M. Cowie, Organometallics, 2012, 31, 1384-1396.

46 M. E. Slaney, D. J. Anderson, M. J. Ferguson, R. McDonald and M. Cowie, Organometallics, 2012, 31, 2286-2301.

47 D. J. Anderson, R. McDonald and M. Cowie, Angew. Chem., Int. Ed., 2007, 46, 3741-3744.

48 W. Schulze and K. Seppelt, Inorg. Chem., 1988, 27, 38723873.

49 B. M. Trost, M. U. Frederiksen and M. T. Rudd, Angew. Chem., Int. Ed., 2005, 44, 6630-6666.

50 B. M. Trost and A. McClory, Chem. - Asian J., 2008, 3, 164194.

51 C. Bruneau and P. H. Dixneuf, Acc. Chem. Res., 1999, 32, 311-323.

52 C. Bruneau and P. H. Dixneuf, Angew. Chem., Int. Ed., 2006, 45, 2176-2203.

53 M. I. Bruce and R. C. Wallis, Aust. J. Chem., 1979, 32, 14711485.

54 M. I. Bruce, G. A. Koutsantonis, M. J. Liddell and B. K. Nicholson, J. Organomet. Chem., 1987, 320, 217-227.

55 L. Ciano, N. Fey, C. J. V. Halliday, J. M. Lynam, L. M. Milner, N. Mistry, N. E. Pridmore, N. S. Townsend and A. C. Whitwood, Chem. Commun., 2015, 51, 9702-9705.

56 M. I. Bruce, A. G. Swincer and R. C. Wallis, J. Organomet. Chem., 1979, 171, C5-C8.

57 D. O'Hagan, Chem. Soc. Rev., 2008, 37, 308-319.

58 W. K. Hagmann, J. Med. Chem., 2008, 51, 4359-4369.

59 M. I. Bruce, Chem. Rev., 1991, 91, 197-257.

60 O. J. S. Pickup, I. Khazal, E. J. Smith, A. C. Whitwood, J. M. Lynam, K. Bolaky, T. C. King, B. W. Rawe and N. Fey, Organometallics, 2014, 33, 1751-1761. 
61 E. F. van der Eide, P. Yang and R. M. Bullock, Angew. Chem., Int. Ed., 2013, 52, 10190-10194.

62 R. M. Bullock, J. Chem. Soc., Chem. Commun., 1989, 0, 165167.

63 M. Bassetti, V. Cadierno, J. Gimeno and C. Pasquini, Organometallics, 2008, 27, 5009-5016.

64 Y. Mutoh, K. Imai, Y. Kimura, Y. Ikeda and Y. Ishii, Organometallics, 2010, 30, 204-207.

65 J. M. Lynam, Chem. - Eur. J., 2010, 16, 8238-8247.

66 K. Onitsuka, M. Nishii, Y. Matsushima and S. Takahashi, Organometallics, 2004, 23, 5630-5632.

67 B. M. Trost and R. C. Livingston, J. Am. Chem. Soc., 2008, 130, 11970-11978.

68 D. G. Johnson, J. M. Lynam, N. S. Mistry, J. M. Slattery, R. J. Thatcher and A. C. Whitwood, J. Am. Chem. Soc., 2013, 135, 2222-2234.

69 A. Škríba, J. Schulz and J. Roithová, Organometallics, 2014, 33, 6868-6878.

70 M. J. Cowley, J. M. Lynam, A. C. Whitwood, M. J. Cowley, J. M. Lynam and A. C. Whitwood, Dalton Trans., 2007, 4427-4438.

71 G. Consiglio and F. Morandini, Inorg. Chim. Acta, 1987, 127, 79-85.

72 J. M. Lynam, L. M. Milner, N. S. Mistry, J. M. Slattery, S. R. Warrington and A. C. Whitwood, Dalton Trans., 2014, 43, 4565-4572.

73 R. P. Hughes, R. B. Laritchev, J. Yuan, J. A. Golen, A. N. Rucker and A. L. Rheingold, J. Am. Chem. Soc., 2005, 127, 15020-15021.

74 R. P. Hughes, Eur. J. Inorg. Chem., 2009, 2009, 4591-4606.

75 C. Bianchini, J. A. Casares, M. Peruzzini, A. Romerosa and F. Zanobini, J. Am. Chem. Soc., 1996, 118, 4585-4594.

76 M. I. Bruce and A. G. Swincer, Aust. J. Chem., 1980, 33, 1471-1483.

77 B. Breit, U. Gellrich, T. Li, J. M. Lynam, L. M. Milner, N. E. Pridmore, J. M. Slattery, A. C. Whitwood, B. Breit, U. Gellrich, T. Li, J. M. Lynam, L. M. Milner, N. E. Pridmore, J. M. Slattery and A. C. Whitwood, Dalton Trans., 2014, 43, 11277-11285.

78 D. B. Grotjahn, C. D. Incarvito and A. L. Rheingold, Angew. Chem., Int. Ed., 2001, 40, 3884-3887.
79 D. B. Grotjahn and D. A. Lev, J. Am. Chem. Soc., 2004, 126, 12232-12233.

80 T. Suzuki, M. Tokunaga and Y. Wakatsuki, Org. Lett., 2001, 3, 735-737.

81 M. Tokunaga, T. Suzuki, N. Koga, T. Fukushima, A. Horiuchi and Y. Wakatsuki, J. Am. Chem. Soc., 2001, 123, 11917-11924.

82 F. Chevallier and B. Breit, Angew. Chem., Int. Ed., 2006, 45, 1599-1602.

83 A similar conceptual loss of " $\mathrm{F}^{+}$" was observed in the case of the metallocyclic complex [III $]^{+}$, although it does appear to be coupled to a hydrolysis reaction.

84 R. T. C. Brownlee and D. J. Craik, Org. Magn. Reson., 1981, 15, 248-256.

85 Y. Ikeda, T. Yamaguchi, K. Kanao, K. Kimura, S. Kamimura, Y. Mutoh, Y. Tanabe and Y. Ishii, J. Am. Chem. Soc., 2008, 130, 16856-16857.

86 Y. Mutoh, Y. Ikeda, Y. Kimura and Y. Ishii, Chem. Lett., 2009, 38, 534-535.

87 M. Otsuka, N. Tsuchida, Y. Ikeda, Y. Kimura, Y. Mutoh, Y. Ishii and K. Takano, J. Am. Chem. Soc., 2012, 134, 1774617756.

88 K. Kanao, Y. Ikeda, K. Kimura, S. Kamimura, Y. Tanabe, Y. Mutoh, M. Iwasaki and Y. Ishii, Organometallics, 2013, 32, 527-537.

89 S. T. Purrington, N. V. Lazaridis and C. L. Bumgardner, Tetrahedron Lett., 1986, 27, 2715-2716.

90 D. D. Steiner, N. Mase and C. F. Barbas, Angew. Chem., Int. Ed., 2005, 44, 3706-3710.

91 A. B. Tamayo, B. D. Alleyne, P. I. Djurovich, S. Lamansky, I. Tsyba, N. N. Ho, R. Bau and M. E. Thompson, J. Am. Chem. Soc., 2003, 125, 73777387.

92 S. J. Lee, K.-M. Park, K. Yang and Y. Kang, Inorg. Chem., 2009, 48, 1030-1037.

93 C.-H. Yang, M. Mauro, F. Polo, S. Watanabe, I. Muenster, R. Fröhlich and L. De Cola, Chem. Mater., 2012, 24, 36843695.

94 F. Kessler, Y. Watanabe, H. Sasabe, H. Katagiri, M. K. Nazeeruddin, M. Gratzel and J. Kido, J. Mater. Chem., 2013, 1, 1070-1075. 